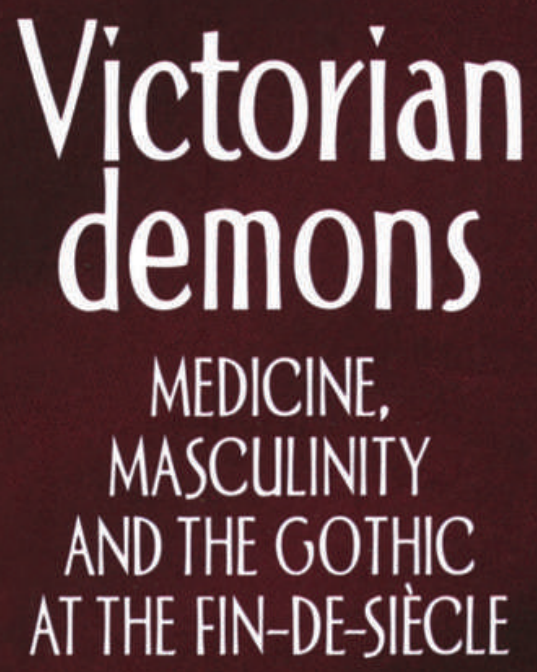

Andrew Smith 


\section{Victorian demons}


For my sisters: Rita, Robyn and Jocelyn 


\section{Victorian demons}

Medicine, masculinity and the Gothic at the fin de siècle

Andrew Smith

Manchester University Press

Manchester 
Copyright (C) Andrew Smith 2004

The right of Andrew Smith to be identified as the author of this work has been asserted by him in accordance with the Copyright, Designs and Patents Act 1988.

Published by Manchester University Press

Altrincham Street, Manchester M1 7JA, UK

www.manchesteruniversitypress.co.uk

British Library Cataloguing-in-Publication Data

A catalogue record for this book is available from the British Library

Library of Congress Cataloging-in-Publication Data

A catalog record for this book is available from the Library of Congress

ISBN 13: 9780719063572

ISBN: 9781526125576 Institutional

First published 2004 by Manchester University Press

First digital paperback edition published 2008 